\title{
CRITICAL ANALYSIS OF SOCIO-ECONOMIC IMPACT OF COVID19 PANDEMIC WITH SPECIAL REFERENCE TO INDIA
}

\author{
${ }^{1}$ Sandesh Yadav ${ }^{*}$ and ${ }^{2}$ Shams Perwaiz \\ ${ }^{1}$ Freelance Researcher, New Delhi, India \\ ${ }^{2}$ Teacher, Sr. High School, Jokihat, Araria, Bihar, India \\ ${ }^{*}$ Corresponding author's email: sandesh_official@yahoo.in
}

\begin{abstract}
Corona Virus Disease (COVID19) shattered and disturbed the horizontal and vertical layers of Indian society. India, a developing nation, prioritized the life of citizens and successfully managed to minimize the losses of lives at the cost of huge socio-economic losses. The collective decision of 'complete lockdown' by the government (both Central and the State governments) saved India from entering into havoc as faced by developed nation's viz. Italy and USA. Though, socio-economic issues related to unorganized sectors, agricultural production, reverse migration and disguise unemployment came into the scene. The present article traces out the stage-wise spread of COVID19 across the globe. The study narrows down to the scenario of India and the spread of COVID19 in the different states of India. Further, the study describes about 'Complete Lockdown' as a measure of social distancing and its impact on socio-economic life of people. Moreover, the study discusses how lockdown helped in minimizing the spread of COVID19 in India. Lastly, discussion on the role of community-based organizations (CBD), non-profit organizations (NGOs) and civil societies in India's ongoing battle against the COVID19 has been incorporated.
\end{abstract}

Key words: COVID-19, Lockdown, Social Distancing, Socio-Economic Impact. Migration

\section{Introduction}

The spread of the virus from the laboratories of Wuhan city, China created havoc in the city and later on, engulfed the entire globe. This virus became popular as 'Coronavirus' though it was officially named as 'Severe acute respiratory syndrome coronavirus 2 (SARS-COV-2)' by the 'International Committee on Taxonomy of Viruses (ICTN) world' and gave rise to 'Coronavirus disease 2019' (COVID-19) named collectively by the World Organization for Animal Health and Food and Agricultural Organization (FAO) of the United Nations. WHO declared COVID19 as pandemic and issued precautionary measures in order to minimize the human-to-human transmission of COVID19. Though, the reverse migration of human beings from China to their respective home countries and conditions were worsened by the mobility within their home country. Ignorance and delayed actions worsened the situation of a country like Italy and the United States of America.

World Health Organization (WHO) divided the world into six regions viz. western pacific region, south-east Asia region, a region of the Americas, European region, Eastern Mediterranean region and others. WHO kept a regular check on the spread of 'Novel Coronavirus (2019-nCoV)' and released situation reports at a regular interval of time. In these, situation reports WHO mentioned 'to and fro' visit China as the major cause of the spread of 2019-nCoV and apart from this, people outside China got infected due to one or the other reason (parcels from China etc.). As per the situation report-22, China was the worst sufferer with 42,708 confirmed cases and responsible for the spread of Coronavirus. The situation report-22 shows that 159 people (across the globe) got infected during their visit to China and on their way back to home infected many others. Likewise, 90 people were reported to be infected outside China (across the globe) due to one or the other 
reason. As per the situation report-22 of World Health Organization (WHO), China got hit by the virus in the worst possible manner with 42,708 confirmed cases out of which 7333 were severe and 1017 people died (as on 11 February 2020). This report reflected a worrisome picture regarding the spread of Coronavirus and things turned into reality. A boom was experienced in the spread of Coronavirus across the globe and cases were reported from every country. Countries like Italy, Spain, and United States of America got hit by the spread of Coronavirus in the worst possible manner.

Table 01: Countries with Maximum Number of Cases of COVID19

\begin{tabular}{|c|c|c|c|c|c|c|}
\hline \multirow[t]{2}{*}{ WHO Region } & \multicolumn{2}{|c|}{$\begin{array}{c}\text { Situation Report - } 22 \\
(11 \text { Feb. 2020) }\end{array}$} & \multicolumn{2}{|c|}{$\begin{array}{c}\text { Situation Report - } 72 \\
(1 \text { April 2020) }\end{array}$} & \multicolumn{2}{|c|}{$\begin{array}{c}\text { Situation Report - } 101 \\
(30 \text { April 2020) }\end{array}$} \\
\hline & $\begin{array}{c}\text { Confirmed } \\
\text { cases }\end{array}$ & $\begin{array}{c}\text { Total } \\
\text { deaths }\end{array}$ & $\begin{array}{c}\text { Confirmed } \\
\text { cases }\end{array}$ & $\begin{array}{c}\text { Total } \\
\text { deaths }\end{array}$ & $\begin{array}{c}\text { Confirmed } \\
\text { cases }\end{array}$ & $\begin{array}{c}\text { Total } \\
\text { deaths }\end{array}$ \\
\hline \multicolumn{7}{|l|}{ Western Pacific Region } \\
\hline China & 42,708 & 1017 & 82,631 & 3321 & 84373 & 4643 \\
\hline Republic of Korea & 28 & 0 & 9887 & 165 & 10765 & 1247 \\
\hline Japan & 26 & 0 & 2178 & 57 & 14088 & 415 \\
\hline Australia & 15 & 0 & 4707 & 20 & 6746 & 90 \\
\hline Philippine & 3 & 1 & 2084 & 88 & 8212 & 558 \\
\hline Malaysia & 18 & 0 & 2766 & 43 & 5945 & 100 \\
\hline Singapore & 45 & 0 & 926 & 3 & 15641 & 14 \\
\hline New Zealand & -- & -- & 647 & 1 & 1129 & 19 \\
\hline \multicolumn{7}{|l|}{ European region } \\
\hline Spain & 2 & 0 & 94417 & 9222 & 212917 & 24275 \\
\hline Italy & 3 & 0 & 10,5792 & 4053 & 203591 & 27682 \\
\hline Germany & 14 & 0 & 67366 & 732 & 159119 & 6288 \\
\hline France & 11 & 0 & 51477 & 3514 & 127066 & 24054 \\
\hline The United Kingdom & 8 & 0 & 25154 & 1789 & 165225 & 26097 \\
\hline Turkey & -- & 0 & 13531 & 214 & 117589 & 3081 \\
\hline Belgium & 1 & 0 & 12775 & 705 & 47859 & 7501 \\
\hline Netherlands & -- & 0 & 12595 & 1039 & 38802 & 4711 \\
\hline Switzerland & -- & 0 & 16108 & 373 & 29324 & 1407 \\
\hline Russian Federation & 2 & 0 & 2337 & 17 & 106498 & 1073 \\
\hline Portugal & -- & 0 & 7443 & 160 & 24505 & 973 \\
\hline Austria & -- & & 10182 & 128 & 15364 & 580 \\
\hline Israel & -- & 0 & 5129 & 21 & 15782 & 212 \\
\hline Sweden & 1 & 0 & 4435 & 180 & 20302 & 2462 \\
\hline Ireland & -- & 0 & 3235 & 71 & 20253 & 1190 \\
\hline \multicolumn{7}{|l|}{ South East Asia region } \\
\hline India & 3 & 0 & 1636 & 38 & 33050 & 1074 \\
\hline \multicolumn{7}{|l|}{$\begin{array}{l}\text { East Mediterranean } \\
\text { Region }\end{array}$} \\
\hline Iran & -- & -- & 44606 & 2898 & 93657 & 5957 \\
\hline \multicolumn{7}{|l|}{ Region of America } \\
\hline United States of America & 13 & 0 & 163199 & 2850 & 1003974 & 52428 \\
\hline Canada & 7 & 0 & 7695 & 89 & 50363 & 2904 \\
\hline Brazil & -- & -- & 4579 & 159 & 71886 & 5017 \\
\hline \multicolumn{7}{|l|}{ African Region } \\
\hline South Africa & -- & -- & 1353 & 5 & 5350 & 103 \\
\hline Algeria & -- & -- & 584 & 35 & 3848 & 444 \\
\hline
\end{tabular}

Source: Corona virus disease 2019 (COVID19), Situation Reports-22, 72, 101, World Health Organization (WHO).

Note: Countries which experienced the boom in cases of COVID19 during 11 February $2020-30$ April 2020 have been taken in the above table.

\section{Indian Scenario of the spread of COVID19}

The number of COVID19 cases has increased rapidly from 3 confirmed cases (as on $11^{\text {th }}$ February 2020 ) to 96,245 confirmed cases (as on $18^{\text {th }}$ May 2020). The data shows that Maharashtra (33053) tops the list and is worst sufferer due to COVID19. The cases majorly reported from Dharavi (Asia's largest slum) due to poor living conditions, improper precautionary measures, congested housing conditions etc. The other factors which were responsible include reverse migration and lack of awareness regarding COVID19. The second in the list is Delhi (National Capital of India) with 10054 confirmed cases as on $\left(18^{\text {th }}\right.$ May 2020) and the possible reasons for such a high number of cases are domestic migration and international migration from countries like the United States of America, Canada, Saudi Arabia, China. In similar lines, Gujarat (11380 confirmed cases) 
being a center of trade and commerce experienced a tremendous increase in COVID19 cases. The same is the case of Rajasthan (5342 confirmed cases) and Tamil Nadu (11224 confirmed cases). The States like Madhya Pradesh (4977 confirmed cases) and Uttar Pradesh (4464 confirmed cases) faced the reverse migration of poor labour class from other States. The States like Telangana (1551 confirmed cases), Andhra Pradesh (2432 confirmed cases), Karnataka (1147 confirmed cases), Kerala (602 confirmed cases), West Bengal (2677 confirmed cases), Jammu and Kashmir (1183 confirmed cases) are about to enter the third stage of community transmission of COVID19. On the other hand, States like Haryana (910 confirmed cases), Punjab (1964 confirmed cases), Bihar (1326 confirmed cases), Odisha (876 confirmed cases), Jharkhand (223 confirmed cases), Uttarakhand (92 confirmed cases), Himachal Pradesh (80 confirmed cases) and Chhatisgarh (85 confirmed cases) have controlled number of cases. Unlike to these, seven sisters viz. Meghalaya (13 confirmed cases), Manipur (7 confirmed cases), Tripura (165 confirmed cases) and Arunachal Pradesh (1 confirmed cases) and Mizoram (1 confirmed cases). The possible reasons for such low figures are the less domestic movement towards these States and less density of population.

Figure 01: Countries with Maximum Number of COVID19 Cases, Western Pacific Region, 2020

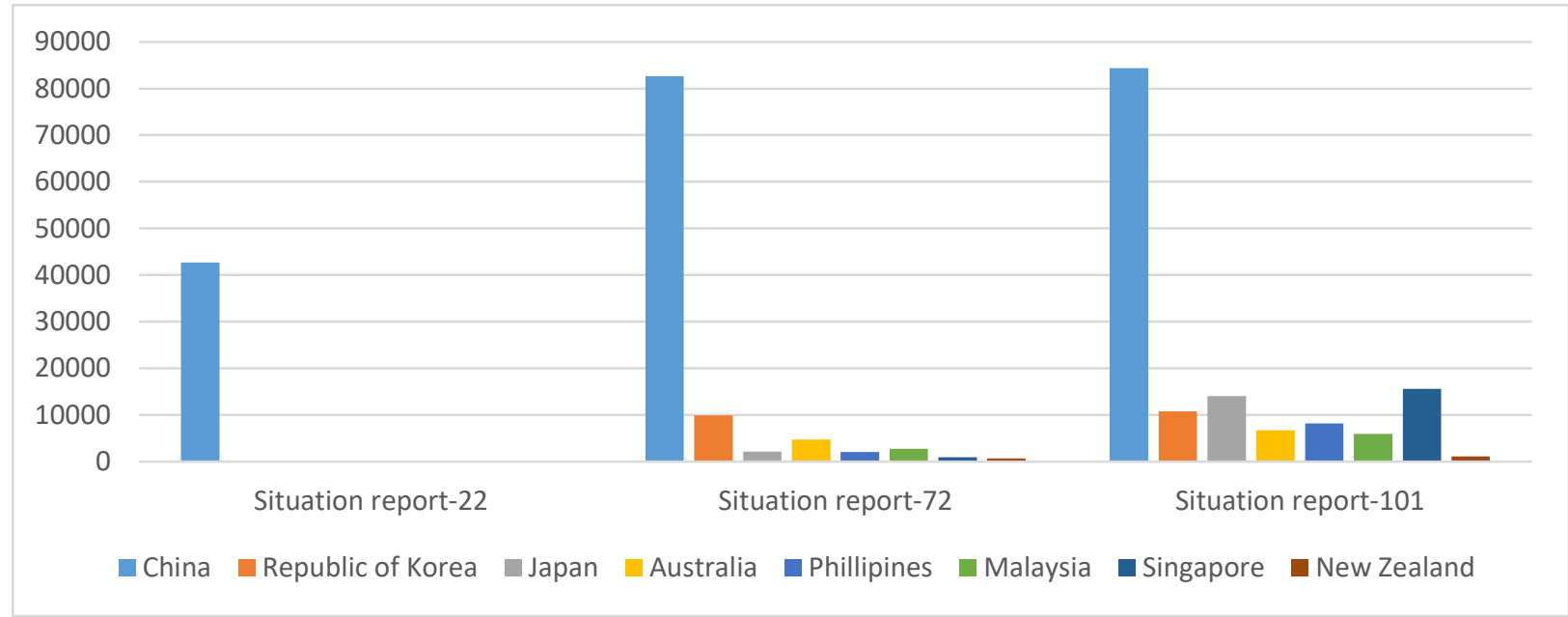

Figure 02: Countries with Maximum Number of COVID19 Cases, European Region, 2020

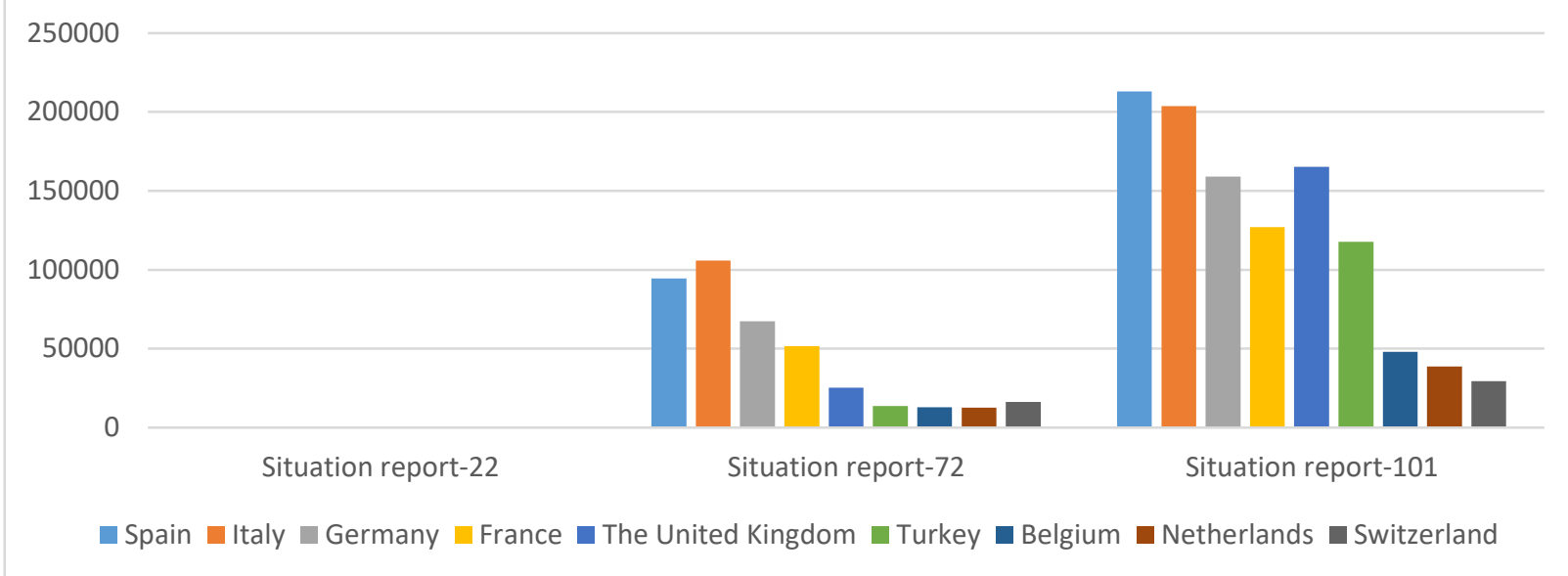


Figure 03: Countries with Maximum Number of COVID19 Cases, South East Asia Region, 2020

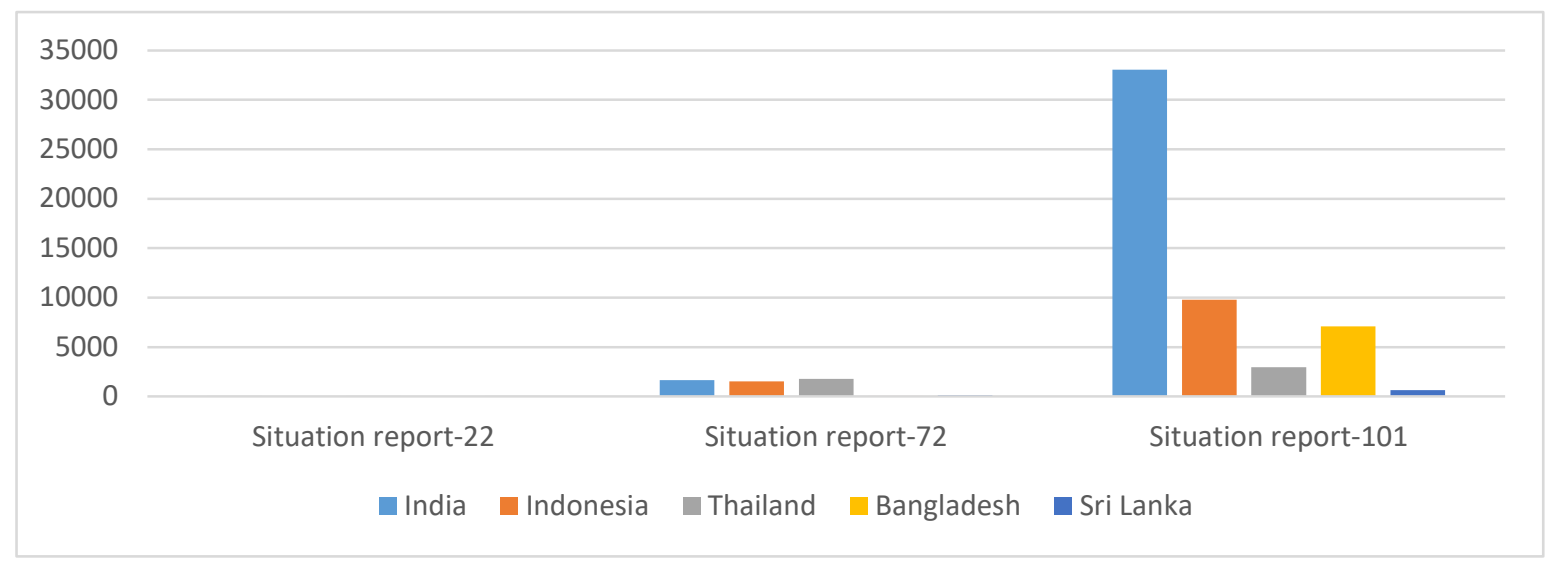

\section{Measures taken by Government of India}

The Government of India (GOI) took the spread of Coronavirus into consideration and issued preliminary warnings and precautionary measures to the citizens to keep themselves safe from the COVID19. But later on, the Government of India realized the seriousness of COVID19 and started taking steps to curb this infection before it creates havoc in our country. The governmental steps and measures can be summed up chronologically as under:

- Preliminary warnings regarding the ways of transmission of Coronavirus and the impact on human body after getting infected. The precautionary measures like use of N95 masks, use of sanitizers, personal hygiene and other Do's and Don't in order to avoid infection.

- Citizens were encouraged to share their travel history (both domestic and international) so that infected travelers can be quarantined properly in order to avoid the spread of Coronavirus.

- To minimize the gathering, Government of India issued orders to shut down schools, colleges, universities, offices (both public and private) and 'work from home' the culture was promoted.

- With a rise in the number of cases in China, Italy, and United States of America compelled the Government of India to visualize the havoc and consequently, implementation of 'Janta Curfew' was done on $22^{\text {nd }}$ March 2020.

- The co-operation of citizens and an ultimate way to minimize the number of cases of COVID19, Government of India announced 'complete lockdown' from 23 ${ }^{\text {rd }}$ March 2020 to $15^{\text {th }}$ April 2020. There was no movement of any kind and citizens were asked to 'stay at home' for their better and healthy future. Though the complete lockdown helped in slowing down the pace of COVID19 cases but the potential danger made the government extend the 'complete lockdown' from $16^{\text {th }}$ April 2020 to $03^{\text {rd }}$ May 2020. Likewise, 'lockdown' was extended from $4^{\text {th }}$ May 2020 to $17^{\text {th }}$ May 2020 in the light of the rapid increase in the number of COVID19 cases. The recent lockdown extension (with some relaxations) took place from $18^{\text {th }}$ May 2020 to $31^{\text {st }}$ May 2020. Moreover, while extending the lockdown government divided the administrative units into the red zone, orange zone and green zone. These zones reduced the panic among the people and also made administrative machinery focus in a much more efficient and effective manner on most affected areas on a priority basis. 
- The 'complete lockdown' served the purpose and helped in braking the infection chain. Following India, several countries of the world declared complete lockdown. These countries include Russia, Italy, USA etc.

\section{Socio-economic Impact}

The 'complete lockdown' on the one hand served the purpose by breaking the 'infection chain' of Coronavirus but on the other hand, resulted in socio-economic impacts (both positive and negative) on the life of people living throughout the length and breadth of the country. The unorganized sector, depleting buffer stocks (agricultural production) and overburdened Police staff and the medical staff. Apart from this, the 'complete lockdown' resulted in some positive outcomes like improved air quality, optimum resource utilization within the family, a realization of human interference level in disturbing the ecological balance.

\section{The Unorganized Sector}

The 'complete lockdown' shattered the unorganized sector in the worst possible way and people working as a tea seller, vegetable seller, cobbler, a rickshaw puller, fruit seller and many others lost their daily source of income. Though the government of India (GOI) made arrangements of breadbutter for the survival of people working in the unorganized sector but COVID19 pandemic with "no end' made poor people to think about their revival in the future.

The unorganized sector faced two major problems:

- Reverse migration. - Disguised unemployment.

As soon as, the government of India declared the complete lockdown, migrant workers and laborers started migrating from 'place of destination' to 'place of origin' and thus, gave rise to 'reverse migration'. This reverse migration resulted 'add on' burden on the economy of 'place of origin'. The administrative machinery at the 'place of origin' becomes responsible for the distribution of survival amenities to the returned migrants from different States. These returned migrants started working as laborers in agricultural fields with or without wages. Consequently, the number of laborers working on a single piece of land increased and resulted in 'disguised unemployment'. The government of India, during the declaration of lockdown extension from $17^{\text {th }}$ May 2020 to $31^{\text {st }}$ May 2020, announced the package of 20 lakh crore rupees for the unorganized sector in order to make them 'Atma Nirbhar' (self-dependent).

\section{Impact on Tourism Industry}

Indian tourism industry suffered from setback due to the spread of Coronavirus and implementation of complete lockdown. The hotel industry, tour and travels and people employed in hospitality sector suffered to a great extent and there seem no recent hopes of a revival of the tourism industry in India. The possible reasons for this are - firstly, fear psychosis among people regarding the infection of Coronavirus discourages them from traveling, secondly, deteriorated economic conditions of people due to lockdown doesn't allow them to go out of budget and thirdly, official workload due to pending work not going to leave them free for longer period of time.

\section{Depleting 'Buffer Stocks'}

Though Indian and its States have enough stocks of food grains to meet out any emergency situations like 'complete lockdown', which is prevailing in India currently as a measure to break the infection chain of Coronavirus. Now, the rate of replenishment of buffer stocks is slow as compared to the rate of consumption. Moreover, decreased agricultural production due to uncertain or extreme weather activities have worsened the situation. The proportion of population, consumption and replenishment does not seem in synchronization. Moreover, in the light of lockdown, farmers are also maintaining stocks for their families and showing less interest in dumping their products in the market. 


\section{Overburdened Police Personnel and Medical Staff}

The government of India declared the strict implementation of 'complete lockdown' and the sole responsibility was given to police personnel to maintain law and order and ensure 'zero mobility' during this period of lockdown. Though, India became a role model for the entire world and was appreciated for its 'complete lockdown'. But police personnel were overburdened with day time duty and night time duty and that too without any protective uniforms in order to avoid themselves from infection. Moreover, they worked in hot and harsh weather conditions throughout the year. The other aspect which came into light in the shortage of police personnel and this shortage needs to be fulfilled by the recruitment authorities as soon as possible. The second and most important 'front line fighters' are doctors and nurses which together constitute medical staff. In this case, also, a shortage of doctors and nurses was observed and due to which junior and under-training doctors and nurses were forced to perform the respective duties. Therefore, the government of India needs to recruit doctors and nurses in a much larger number in the near future.

\section{Improved Air Quality}

The 'zero mobility' of vehicles resulted in zero vehicular exhaust; zero SPM and RSPM and consequently, air became clearer than ever before. The environmental visibility increased and the clear blue sky became a regular scene. The metropolitan cities like Delhi and Mumbai got rejuvenated in terms of air quality and environment.

\section{Optimum Resource Utilization within the Family}

The lockdown resulted in a limited supply of resources which made people utilize the available resources in an optimum manner. Thus, people learned to give up their high consumption patterns and acquired low consumption patterns. Consequently, distribution of resources became fairer and fairer and maximum a number of people got benefited.

\section{Level of Human Interference in Disturbing the Ecological Balance}

During the period of lockdown, we came across several news like peacocks roaming on the streets of Madrid, Spain; elephants on the streets of Rishikesh, Uttarakhand; Dolphins in waters of the marine drive of Mumbai, Maharashtra; wild animals on the streets of Chandigarh, Punjab; and many more incidences of visibility of wild animals was reported across the world. This increased visibility of wild animals on the streets of cities shows that noisy-voices life of human beings forced peace-loving wild animals to go and hide in the core of forests. Moreover, improved air quality, environmental visibility shows that anthropogenic activities responsible for the deterioration of environmental conditions and ecological balance.

\section{Conclusion}

Though, we suffered losses at the economic front but imagine the scenario of Italy in the context of India. Italy with the best medical infrastructure in the world failed to cope up with the rapidly spreading Coronavirus. Now, if we talk about India then we are far behind in terms of medical infrastructure and the complete lockdown was the only measure to protect people from getting infected by the Coronavirus. The fight against COVID19 is still going on and citizens along with non-governmental organizations (NGOs), community-based organizations (CBOs) came together to provide all possible help to the needy people.

\section{References}

1. World Health Organization (2020). Coronavirus situation report-22 released on 11 Feb. 2020

2. World Health Organization (2020). COVID19 situation report-72 released on 1 April 2020

3. World Health Organization (2020). COVID19 situation report-101 released on 30 April 2020

4. www.covid19india.org

5. http://covidvisualizer.com 